\title{
THE CHANTING FROG: SPECIECISM AND THE POSSIBILITY OF COMMUNICATION IN ISSA'S HAIKUS
}

\author{
Enrique Galván Álvarez \\ Universidad Internacional de La Rioja
}

\section{Abstract}

The aim of this paper is to discuss the role of animals, particularly frogs, in Kobayashi Nobuyuki (1763-1827), "Issa"'s poetry from a perspective that identifies common and parallel threads in Anarchist, Shin Buddhist and Ecocritical thinking. The interrelationship between these three lines of thought is relevant to the frog poems of Issa, since they address the issue of speaking non-humans and dismantle power relations by following a particularly egalitarian interpretation of Buddhist thought. Issa's Buddhist practice of listening de-centers the poet while empowering the frog as a speaking subject, and thus disrupts speciesist thinking. Issa's vision is not only in consonance with a certain Buddhist worldview but can also be said to be anarchist, in so far as it conceives a fluid world without hierarchies or authority structures. These anarchist and Buddhist themes can shed some light on ongoing ecocritical discussions about non-human voice and agency.

Keywords: Kobayashi Nobuyuki, "Issa”'s Haikus, Chanting Frogs, Speciecism, Anarchism, Buddhism.

\author{
EL CANTO DE LA RANA: ESPECISMO Y POSIBILIDAD \\ DE COMUNICACIÓN EN LOS HAIKUS DE ISSA
}

\section{Resumen}

Este artículo pretende tratar el rol de los animales, específicamente de las ranas, en la poesía de Kobayashi Nobuyuki (1763-1827), más conocido como «Issa», desde una perspectiva que identifica paralelismos comunes en los presupuestos anarquistas, budistas Shin y ecocríticos. La interrelación de esas tres líneas de pensamiento es relevante en la obra poética de Issa, ya que sus poemas tocan el tema de la comunicación no-humana al tiempo que desmantelan las relaciones de poder por medio de una interpretación particular e igualitaria de los preceptos budistas. La práctica budista de escuchar de Issa descentraliza la voz poética a la vez que empodera a la rana como sujeto hablante, alterando así el pensamiento especista. La visión de Issa no sólo es acorde a una cierta visión budista del mundo sino que además tiene concomitancias con la del anarquismo, en tanto concibe un mundo que fluye sin jerarquías ni estructuras de autoridad. Esta temática anarquista y budista puede arrojar cierta luz sobre la problemática actual de los discursos ecocríticos acerca de dar voz a lo no-humano y dotarle de «agencialidad».

Palabras Clave: Kobayashi Nobuyuki, «Issa», haikus, ranas cantoras, especismo, Anarquismo, Budismo. 
Kobayashi Nobuyuki (1763-1827), better known as Issa, was famous for his numerous and humorous haikus, which portray encounters with or among non-human, and often speaking, animals. Such encounters are, sometimes explicitly and sometimes implicitly, framed in Issa's particular appraisal of Jodo Shinshu doctrine $^{1}$. Jodo Shinshu is a Japanese Buddhist tradition based on a radical, and potentially egalitarian, re-interpretation of Buddhism, first formulated by Shinran Shonin (1173-1126). Though Jodo Shinshu's social praxis cannot be said to have always fulfilled the liberative promise implicit in its tenets, one of Shinran's, and his master Honen's, core concerns was to formulate a Buddhism that could be practiced by everybody, disregarding social, gender or religious hierarchies. Although nonhuman animals were not explicitly included in Shinshu doctrines as candidates to become Buddhas through the "easy" and universal practice of nembutsu (saying the Buddha's name), in Issa's poetry they not appear only saying the nembutsu but also chanting back to priests like Issa. This can be seen as being in consonance with the latent egalitarianism present in many Jodo Shinshu doctrines but also as an innovation introduced by the haiku poet.

Issa's original way of conversing with non-human animals, and especially frogs, can offer an interesting insight into ongoing discussions about the agency and loquacity of nature (Abram, Manes). Although the potential of Buddhist ideas for discussing embodiment across species (Rutschmann-Byler), nature's agency and the ability to communicate have been addressed, these discussions remain largely centered on Zen or Shingon (David Jones), without mentioning the more popular and widespread forms of Buddhist devotion, such Pure Land Buddhism (to which Jodo Shinshu belongs to). Lanoue's Pure Land Haiku insightfully analyses Issa's relationship to the non-human from the standpoint of Jodo Shin ideas, but the political implications of Issa's poetry are not fully spelled out. Issa's animal poems are a great opportunity to bring Pure Land Buddhism into discussions about agency / loquacity by showing how they acknowledge conversations with a nature that approaches and talks to the poet. However, Issa's very personal and emotional appropriation of Jodo Shin ideas does not only constitute an instance of humans listening and learning from non-humans but also carries a potentially subversive political message. By playfully confounding the boundaries between himself and the non-human voices of his poems, Issa decentres human subjectivity, enabling a number of horizontal and anarchic relations between species to emerge. These relations, though not necessarily always or entirely devoid of power, certainly bring into question (if not demolish) a hierarchical and anthropocentric Chain of Being,

${ }^{1}$ I use the term Jodo Shinshu in the sense that Shinran uses it, to refer to the teaching he expounds in his various writings. I use the terms Jodo Shinshu, Jodo Shin, Shin, Shin Buddhism or Shinshu indistinctively to refer to Shinran's Buddhism but, unless explicitly stated otherwise, I do not mean the whole of Jodo Shinshu thought elaborated by Shinran's followers after his death. When writing about the various institutions that have preserved Shinran's writings and claim to inherit his legacy I explicitly refer to them as Jodo Shinshu institutions. 
favouring multiple, unexpected and fleeting exchanges with non-human animals which constantly modify the human subject.

The aim of this article is to discuss Issa's animal poems, and in particular his frog poems, from a perspective that identifies common and parallel threads in anarchist, Shin Buddhist and ecocritical thinking. The interrelationship between these three lines of thought is relevant to the frog poems of Issa, since they address the issue of loquacious non-humans and dismantle power relations by following a particularly egalitarian interpretation of Buddhist thought. In order to ground this anti-authoritarian reading of Issa in the various streams of thought it draws inspiration from I will first outline the (dis)connections between them and their suitability for looking at Issa’s frog haikus².

It is worth noting that the three streams of thought chosen for discussing Issa's works have a history of interaction with each other. Although this is often a relatively short and fragmented history (especially in the case of Shin Buddhism and anarchism) it shows how anarchists, ecocritics and Buddhists have been interested and willing to talk and learn from each other. There are shared aims and concerns within the three large, heterogeneous and complex spaces I am choosing to refer to as anarchism, Buddhism and ecocriticism. Decentralization and disruption of hierarchies seems perhaps the most basic commonality, albeit understood in rather different, though not incompatible, ways. Most forms of ecocriticism wish to challenge the centrality of the human subject in order to pave the way for a more bio-centric approach in which hierarchical relationships between humans and non-humans are brought into question and dissolved. This is also the social insight of many forms of anarchism, which traditionally aimed to dismantle the authoritarian and coercive structure that supported both the state and the capitalist establishment.

In fact Richard Ryder's coining (and Peter Singer's popularization) of the term "speciesism" as structurally analogous to racism or sexism has been incorporated into many socially progressive agendas, anarchists ones not being an exception. Thus, many anarchists today consider the hierarchical relationship that subordinates nature to humans as another power structure to be disrupted (Pattrice Jones). Anarchists have in fact been engaged in debates about Deep Ecology for at least five decades, criticizing the power dynamics implicit in the logic of civilization and offering a larger critique of hierarchies through the notion of Social Ecology (Bookchin). Ursula K. Le Guin combines in some of her novels ecological and anarcho-primitivist themes (Marshall 690). The term "anti-speciesism" has come to feature in anarchist literature together with more traditional labels like anti-capitalism, anti-fascism, anti-sexism

${ }^{2}$ It must be noted that frogs have long featured in Japanese mythology and folklore, largely as harbingers of rain and therefore, good harvests, fertility and prosperity. Furthermore, since the character (kanji) for 'frog' and the character for 'return' are homophones they have been associated with home-coming journeys and safe returns. Although Issa's frogs sometimes appear linked to these traditional signifiers, especially rice fields and the rain, they are also portrayed in innovative and unconventional ways, by being associated with Buddhist practice and through Issa's very personal, emotional and dialogic approach to the amphibians. 
or anti-racism. Also, Animal Liberation groups often have anarchist connections or inspirations, for instance their opposition to the notion of animal property, which animates their actions of releasing living beings from meat factories and other places of confinement, is a combination of a wish to acknowledge the voice and agency of animals and a critique of private property which resembles anarcho-communist positions (Best).

Although Buddhism might seem at odds with these philosophies, its central aim is also to disrupt what is arguably another hierarchical or power relation: egotism. By disrupting the epistemological and ideological processes that enable us to regard ourselves as the centre of the universe, Buddhism strives towards a more open, rhizomatic, changing, sensitive and empathic subject. The positive side of the negation or deconstruction of the self (and its claimed centrality) is compassion for others, which might be seen as the actualization of a non-hierarchical and egalitarian view of the world. The decentralized, selfless or enlightened subject is thought to naturally feel with others without any kind of restriction, reservation or prejudice. Contemporary Shin scholar Taitetsu Unno explains this notion of subjectivity through the old Buddhist metaphor of the house builder: "The "house builder' is the ego-self that builds a protective wall around itself. [...] Liberation from the house-builder makes possible a newly realized self that is interrelated and interconnected with all beings" (145).

The emphasis on compassion and the idea that all beings possess Buddha nature is somewhat more present in Mahayana schools, despite not being entirely absent in Theravada Buddhism. However, this vision of all beings, and in a sense all phenomena, having the same interdependent nature has very rarely led to egalitarian social models and has not prevented the exploitation of nature in modern industrialized Buddhist countries (e.g., Japan, China or Taiwan). Nevertheless, the egalitarian and implicitly anti-authoritarian potential of Buddhism ${ }^{3}$, has been engaged by individual Buddhists over the centuries to create projects that articulate strategies of resistance to oppression and radical visions of society.

The intersections between Buddhism and Anarchism do not begin with Gary Snyder's famous 1961 essay "Buddhist Anarchism", even though it is possibly the first instance of the two terms appearing entwined in English. In order to explore the roots of what today is called Engaged Buddhism we need to look at the first Buddhist country to become industrialized and, therefore, receptive to the social movements that emerged in the West as the product of industrial / post-industrial society. It is in early $20^{\text {th }}$ century Japan where we find the first Buddhist anarchists, who used Buddhist thought to criticize the Meiji regime, capitalism and war. Interestingly enough the more politically active Buddhists belonged to the "newer" Japanese Buddhist schools (e.g., Jodo Shinshu, Soto Zen), which broke free from

${ }^{3}$ Apart from Buddhist anarchists like Gary Snyder, Uchiyama Gudo (Victoria 38-47) or Takagi Kenmyo, who had a vested interest in outlining the anti-authoritarian potential, historians of anarchists have also acknowledged said potential (Marshall 60-65). 
established Buddhist and secular institutions and conventions during the Kamakura period (1158-1333) and reformulated Buddhism so it could be accessed and practiced by people not belonging to the monastic or aristocratic elites.

The more democratic and popular forms of Buddhism that emerged out of the Kamakura period were the ones that, despite centuries of becoming co-opted by the various authoritarian structures of successive feudal Japanese societies, were more receptive to engage with radical politics at the turn of the $20^{\text {th }}$ century $y^{4}$. This has not only to do with the social position of those schools but also with their doctrinal foundations, which already contained the potential for envisioning a non-hierarchical society (even though the schools were often highly hierarchical, mimicking the feudal social context in which they thrived, especially during the Tokugawa period) ${ }^{5}$. Two of the most important figures in the history of Japanese Buddhist anarchism were a Jodo Shin priest, like Issa, named Takagi Kenmyo (1864-1914) and a Soto Zen monk, Uchyama Gudo (1874-1911). Gudo explicitly called himself a Buddhist anarchist and was executed by the government as part of the High Treason Incident (Taigakyu Jiken, 1911) for his subversive writings. Takagi Kenmyo called himself a Buddhist socialist but his writings have a decidedly libertarian flavor (see Kenmyo); he took his own life in prison in 1914. Both figures were repudiated by their schools at the time, dispossessed of their clerical status and condemned. However, not few Zen and Shin Buddhists have reclaimed their thought after the defeat of Japan in World War II. Although they did not explicitly criticize the environmental impact of Japan's quick industrialization under the Meiji regime, they were harshly opposed to the militaristic, capitalist and nationalistic establishment that brought it about. Especially in Uchiyama Gudo's writings, there is a yearning for pre-modern society which resonates with the anarcho-primitivist critique of civilization (Victoria 38-47).

The interconnections between Buddhism and ecocriticism are, however, better known and less overtly connected to radical politics. Many of them arise in the context of Engaged Buddhism and the Counterculture from the 1960s onwards. The work of Joanna Macy is a good example of how both forms of thought can be combined in a contemporary global context. Buddhist ideals of compassion and protection of life can easily be adapted to an environmentalist agenda (see Macy). Buddhist tenets such as interdependence and mutual causality (skt. pratitya samtupada) are readily compatible with deep ecology and the critique of anthropocentrism. However, Buddhism has not been, historically, overwhelmingly anti-speciesist and despite its ultimate aim at complete decentralization of the subject, it has often reproduced in its path towards such goal many hierarchical relationships, both in thought and action. Hence Buddhist institutions have often mimicked the oppressive power structures of the societies in which they developed and, by extension, the

${ }^{4}$ For a discussion of this process and how it affected the Shinshu institution(s) see Shimazu.

5 In this regard Kasahara explains how people were forced to be registered with a certain Buddhist school or institution, along social lines, thus: "the imperial family is in Tendai, the peerage is in Shingon, the nobility is in Jodo (Honen's followers), the Samurai is in Zen, the beggar is in Nichiren, and Shin Buddhists (Shinran's followers) are at the bottom" (2). 
establishment's attitudes towards their underclasses (e.g. women, outcasts, nature). Nonetheless, there have also been Buddhist radicals who using Buddhist ideas in innovative ways posed a critique to the power structures of their time, both within Buddhist communities and in their societies at large.

One such radical innovator was Shinran $\left(12^{\text {th }}-13^{\text {th }}\right.$ century) and another (in the field of poetry) Kobayashi Issa $\left(18^{\text {th }}-19^{\text {th }}\right)$. What follows is an imaginary dialogue between the two which at some point might transform into a different kind of conversation, initiated by frogs, not humans. To elucidate the complexity of Shinran's thought is beyond the scope of this chapter, however, some aspects of his substantial rereading of the Mahayana Buddhist canon need to be outlined to understand how they enable Issa to write poems in which animals embody the voice of the Buddha. Shinran's re-interpretation of Buddhist doctrine comes about against the backdrop of both pre-existing Pure Land thought and some Tendai notions, such as universal enlightenment. Although the idea of the pure land of Amitabha Buddha, a realm where everybody naturally and effortlessly awakes to the impermanent and interdependent nature of things (the essence of the Buddhist teaching or dharma), comes originally from the early days of Mahayana in India $\left(2^{\text {nd }} \mathrm{c}\right.$. BCE $)$, a Buddhist stream of thought centered on such realm only developed a few centuries later in China $\left(5^{\text {th }} \text { century CE }\right)^{6}$. As time elapsed from the Buddha's disappearance from the world ( $5^{\text {th }}$ century BCE) there was a widespread belief (especially in China and later Japan) that it was impossible for human beings to realise their Buddha-nature in this world. However, it was possible to be born in a different realm where enlightenment will happen quickly and without strenuous discipline. Such realm was Amitabha's Pure Land and the practices leading to birth in it became increasingly simplified as the Pure Land tradition moved from China to Japan. It is worth mentioning that the Pure Land tradition was never a school until the followers of Honen and Shinran respectively developed the Jodo Shu and Jodo Shinshu schools in $13^{\text {th }}$ and $14^{\text {th }}$ century Japan.

Until then the various Chinese and Japanese monks that made birth in the Pure Land the focus of their practice did not belong to a particular school or were necessarily students of a particular teacher, or were part of institutions that were not necessarily or exclusively Pure Land oriented. They read texts on the Pure Land and developed faith in its vision, contributing to this loosely defined tradition more

\footnotetext{
${ }^{6}$ Amitabha is a Sanskrit word literally meaning infinite or boundless light. In Japan s/he is usually referred to as Amida, and I shall use the term Amida henceforth. Unlike Gautama Buddha, the historical Buddha who is believed to have lived in India in the $6^{\text {th }} \mathrm{BCE}$, Amitabha transcends space and time. The origin of the idea of Amitabha is thus explained by modern Shin scholar Shigaraki: "We might say that Amida Buddha arose within the sincerity of the hearts and minds of people who praised and revered Gautama Buddha after his death. The notion of Amida Buddha was formed through the process of a gradual abstraction both of Gautama's life and of the inner reality of Gautama's experience of awakening - his enlightenment as a buddha- which he fulfilled at the risk of his own subjectivity. This was symbolized as Amida Buddha, the Buddha of immeasurable light and life, the Buddha possessed of infinite reach throughout space and unlimited connectivity throughout all time" (26-27).
} 
commentaries on the relevant sutras. This is partly due to the fact that birth in the Pure Land was not imagined to require complicated practices which would justify the guidance of a teacher or the support of a large monastic institution. Already in China, Pure Land Buddhism became associated with the lay masses as opposed to the monastic elites, since it offered a way for people who could not afford to withdraw from lay life and adopt a meditative regime as monks or nuns. This becomes more evident in Japan, where exegetes like Genshin (942-1017) or Honen (1133-1212) make the repetition of Amida's name with sincerity the only practice required for birth in the Pure Land. This was a practice that anyone and everyone could accomplish, regardless of gender (women, not even nuns, were given access to the same esoteric teachings that men could study), social class (reciting the name did not cost any money unlike other practices common to lay people such as financially supporting monasteries or monks or commissioning the building of stupas or copies of the sutras) or intellectual capacity (no scholarship was required for the recitation of Amida's name, only a mind of trust or confidence in the vow of the Buddha to save all sentient beings). There was no need to follow precepts either which also enabled fishermen or huntsmen, who were previously discriminated because their livelihoods run against the Buddhist principle of respecting life.

Thus the Pure Land tradition started off as a more horizontal and uninstitutional (if not entirely anti-institutional) form of Buddhism. No teacher was required to initiate or authorize the student to recite the nembutsu and no institution was imagined to preserve, channel or mediate Amida's enlightening influence ${ }^{7}$. This influence, imagined to be contained in the nembutsu itself, works of its own accord and spontaneously awakes faith in the individual making him or her recite the name; his or her first experience of oneness with the Buddha was regarded as assurance of birth in the Pure Land and eventual attainment of Buddhahood. This became the thrust of Shinran's message, which rejected the need of constantly repeating the name as some form of self-discipline and regarded the nembutsu as the natural expression of trust, insight and assurance and not as a means to achieve a given goal. In this sense it is not the human subject who calls on the Buddha Amida in order to become a Buddha, but Amida who calls on the human subject to go to the Pure Land and then return to this world to fulfill the work of a Bodhisattva by helping countless others. From this perspective, the nembutsu is not a practice

7 Although in the Jodo Shinshu and Jodo Shu traditions the role of the teacher as transmitter of the teachings or the nembutsu is deemphasized, most nembutsu practitioners would have learned this teaching from other human beings and so, keeping with Buddhist conventions, would refer to them as their mentors. However, some key figures in the history of Pure Land Buddhism like Tao Cho (562-645) or Honen regarded as their mentors monks who were long dead before they were born and whom they never were able to meet, except through their writings. Shinran is famously quoted in Tannisho VI (see Strategies 6) saying that he has not a single disciple, despite many regarded him as a teacher. He often speaks of Honen as his teacher but their relationship is not a straightforward or traditional one (see Bloom "Loyalty"). In line with this variegated tradition some modern Shin followers would regard themselves as students of contemporary Shinshu priests or lay persons but others would say they are disciples of Shinran, the historical Buddha or the Amida Buddha. 
human beings can apply themselves to but an expression of the Buddha's agency through their minds and body.

It is worth mentioning that although the Buddha Amida might evoke a theistic figure, this is merely a narrative simplification of the logic of Pure Land Buddhism. In actuality, the Buddha Amida is "the medium through which we are made to realize jinen [naturalness, spontaneity]" (Shinran "On Jinen Honi" 30). The word amida, a Japanese transliteration of the Sanskrit amita (literally no-measure, boundless), is simply a means to lead the human mind towards what Shinran calls "the supreme Buddha", which is "formless" and "natural"8. This supreme Buddha is not a person but the state of Buddhahood itself, which lies buried in the heart of every being, and expresses itself freely and spontaneously (jinen) when unlocked. The Buddha Amida stands as a narrative mediator between our narrative selves and the supreme Buddha from which the narrative self or ego has grown disconnected. Although the Buddha Amida stands for what is most central to any sentient being, she or he appears as an-other in relation to the ego, the narrative self. She is the ego's rescuer but also its dismantler. On one hand the Buddha appears as a savior that sheds light on a self completely unable to illuminate or overcome itself, destroying its negative conditioning and carrying it to the Pure Land. On the other hand by illumining the ego the Buddha brings about self-questioning and eventually the realisation that the self is merely a narrative construction, since its existence is contingent and impermanent, owing its existence to multiple causes and conditions.

Thus the Buddha's agency is not the supernatural agency of a god, but the collective agency of all phenomena and all beings. Such agency is at the very root of human existence, since it is thought to express itself in the countless causes and conditions that enable our lives. These causes and conditions are not imagined as lifeless, abstract events, but as living and sentient beings, places and situations which constantly nurture our individual existences. This interpretation of Amida as collective agency can be traced back to the Chinese monk Tan Luan (476-542), retrospectively claimed as patriarch by the Jodo Shinshu tradition, but has also gained prominence among modern Shin thinkers like Takamaro Shigaraki. In fact Shigaraki regards the term tariki (literally other power or the power of the Buddha as opposed to the power of the ego-self) as synonymous to "conditional arising" and "depending on others" (91). In the same way that our life is enabled by countless other beings so is our awakening, our becoming Buddha. The dismantling of the narrative self through realising its fundamental dependence on others must also

8 The term jinen has a complex history, being first appropriated by early Chinese Buddhist translators from Daoist sources in order to translate the Buddhist sutras from Indian languages. Shinran takes it from the translated sutras and gives it a slightly new meaning. In Takayama's word: "The notion jinen is used by Shinran in various ways and with different shades of meaning. It basically denotes two meanings. On the one hand, it refers to ultimate reality, the supreme formless Buddha [...] On the other hand, it refers to the way that ultimate reality appears in the form of Amida in order to awaken beings to itself [...] The term jinen thus signifies ultimate reality as well as the way in which ultimate reality works for our salvation" (137). 
happen through the collective agency of those countless others. The ego's efforts at seeing through its own delusion in introspective isolation are in vain, since they only reify the illusion of its own independent, coherent and discrete existence. Its dismantling and awakening is the work of the other: the "supreme Buddha" as the other within, but also those that the self perceives as others, whether human or non-human?.

When interpreted as a radical outcome of dependent origination the teaching of Amida Buddha regards all beings, whether perceived as sentient or non-sentient, as participating in the endless work of the Buddha, which is to awake all beings to their mutual dependence and contingency. However, the Buddha does not stand as a transcendent figure manifesting through these interdependent phenomena but is in fact non-dual with them. Thus Shin followers often speak of the kindness received from family and friends or even fortunate events as Amida's compassion. These feelings of gratitude are not towards the benevolent, superior or omnipotent will of a deity but function as acknowledgments of the deep connections that enable and nurture human existence. The story of Amida posits a horizontal relationship a mong beings; it is a narrative that highlights their mutual dependence and equality in regards to their hidden potential (i.e., the superior Buddha or Buddha nature). Amida can be said to be this potential: the dynamic wish that makes beings grow towards a more decentred sense of self which understands its dependence and naturally responds by acting empathically. However the Buddha cannot make the narrative self aware of this dynamics if it was not by the interaction with everything that is other to the self, from unknown and marginalized aspects of that very self to other beings. Consequently Shinran does not prescribe a method for attaining self-decentering and regards the nembutsu merely as a spontaneous and grateful response to the realisation of interdependence. The closest to a path in Shinran's thought is monpo, listening to the dharma or teaching of the Buddha. This listening can be understood literally as engaging with the Buddhist teaching, and particularly the teaching of Amida Buddha, but also in a more open way as listening or paying attention to the other(s). After all the word dharma does not only refer to the teaching, but to phenomena or experience themselves. Thus listening to the dharma could be freely translated as paying attention to experience or hearing the voices of phenomena, which are always affected and shaped by many others. Through this interaction, to put it in Shin technical terms, "the isolated namu realizes its oneness with amida butsu, and our wholeness is affirmed as NAMU-AMIDA-BUTSU" (Unno 33). The isolated and narrowly defined self realizes its identity with the vast

9 To make clear that the term tariki, literally "other power", is not meant to imply a power completely external to the individual but something latent within. Mark Blum offers these suggestions for the translation of this term: "Tariki, also called butsuriki [buddha-power] or ganriki [vow-power], denotes the transcendent power of a buddha, but because of the ambiguity inherent in the relationship between buddha and self in the tathagatagarbha [literally buddha-seed, but generally translated as buddha nature]doctrines, which have always been close to Pure Land thought, 'spiritual power beyond the known self' is a more apt gloss for this term" (8). 
net of interdependence that supports and decentres it at once. All that is left for a self that has been thus opened is to live a life of gratitude towards others based on the verbal recitation of the nembutsu, the acknowledgement of its deep connections and ultimate powerlessness (qua isolated self).

Furthermore, and returning to the more narrative and popular version of Amida's teaching, since Amida vowed in the remote past that every sentient will be born in the Pure Land, every being has a direct connection with Amida and does not need the mediation or confirmation of institutions. The self is awakened to the teaching through interaction with others, whether human or non-human. However, although Shinran clearly states that he had not a single disciple his followers created a church-like institution to preserve first his ashes and then his teachings (Dobbins 63-155). This move eclipsed the more radical and egalitarian aspects of Shinran's thought, as it was oriented to obtain the establishment's approval and imitated its highly hierarchical ways. Shinran speaks of the sangha or Buddhist community as one of "fellow travellers" (dobo dogyo) without room for hierarchies; all beings are equally selfish and are equally the object of Amida's compassion.

Nevertheless, even members of the Shin clerical body, which was highly stratified and pyramidal, can be seen as embodying the egalitarian ethos of Shinran. Issa and his poems are a good example. Since the call of Amida Buddha could manifest in any form and from any other, for Issa, a great lover of frogs, it appears in their croaking ${ }^{10}$. Thus three of his haikus play with this motif:

Praising the Buddha

Mouths gaping wide...

Frogs

They praise Buddha too

Frogs on a rock

In a row

Praising Buddha

In a row in a rice field...

Frogs $s^{11}$

The sound of frogs croaking is rendered in Japanese as "namu-namu", the first word of Namu Amida Butsu (the most popular Japanese utterance of nembutsu), which corresponds to the Sanskrit word for "I trust" or "I take refuge in". For Issa this is the call of the Buddha being addressed to him. In this context frogs become

10 Why Issa loved amphibians, dedicating as many as two hundred of his haiku to them, is never explained in his writings. Although they are popular animals in the Japanese imagination Issa's creative engagement with frogs does not respond to received or established ways of depicting frogs and seems to be an expression of a personal fondness.

${ }^{11}$ Each of Issa's haikus quoted in this chapter are from Lanoue's translation as they appear in his most comprehensive website: http://haikuguy.com/issa/. 
the teacher that reminds him of the nembutsu, they are the vehicle through which Amida's voice reaches him from the outside, thus making him aware of Amida's voice within. By presenting frogs as teachers, Issa dissolves the speciesist power structure that regards animals as inferior and fundamentally different from humans. Even though most Buddhists would agree that animals ought to be respected and welltreated, in Buddhist theory and practice they are still considered inferior subjects. Animals cannot awake to their Buddha nature and are often portrayed as ignorant creatures who ought to wait to be reborn as humans in order to then become Buddhas. Nonetheless, Issa breaks with such idea, deeply ingrained in Buddhist thinking, by not only considering frogs higher than himself but by letting them teach him. Of course Issa can only reproduce this in human language and through his Buddhist cultural conditioning, but he is not talking to the frogs, but letting the frogs speak to him. As expressions of Amida's compassion, frogs are not to be sought out but represent the active and initiating side in this encounter with Issa.

At other times it is Issa who approaches the frogs and intervenes in their affairs in a tender, playful way:

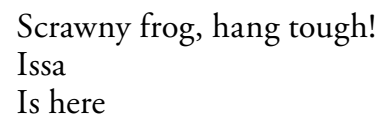

In this haiku Issa acts out of sympathy as a protector of a "scrawny frog". In fact, Lanoue explains how Issa often identifies in his writings as "impoverished and hungry" and therefore feels a natural affinity with this skinny frog (Lanoue Haiku). Although in this haiku the frog does not speak to Issa as such, through his empathy Issa brings forth the frog's voice, falteringly calling for help. In fact, this faltering and silent voice resembles that of Issa's persona in some of his more personal haikus. Issa's empathy is not patronizing or condescending, but is based on some form of humorous mutuality, it is a dialogic form of compassion based on his own weakness. A similarly mutual flavor can be appreciated in one of Issa's best known haikus:

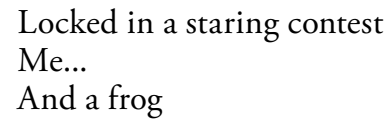

In this case the frog and the poet stand on equal terms, wordlessly communicating with each other. Through the "staring contest" both poet and frog become absorbed to the point they are not sure who is looking at whom, or writing about whom. "Locked" in this wordless dialogue, both subjects become confounded, momentarily dissolving relations of power. Lanoue relates this haiku to Shinran's notion of "fellow travellers on the path" (Haiku), which imagines all beings in an egalitarian relation in regard to the Buddha. However, whereas Shinran egalitarianism embraced, in practice, only humans, Issa goes one step further by including frogs (among many other animals). Shinran did not believe that animals were not 
the object of Amida's compassion, which melts the boundaries between the Buddha and suffering beings, regardless of their human or nonhuman shape. In fact, blending the Tendai notion of universal enlightenment and the Pure Land idea of Amida's all-encompassing compassion, Shinran goes even further to include vegetation and landscape: "This Tathagata [Amida] pervades the countless worlds, it fills the hearts and minds of the ocean of beings [including animals]. Thus, plants, trees and land all attain Buddhahood" ("Notes" 461). Nonetheless, animals, plants or mountains could not be part of the Buddhist community as a social institution. Issa, however, includes frogs in his imaginary, all-embracing fellowship, something that naturally follows from Shinran's teaching but that had not been explicitly spelled out before.

Issa does not only portray frogs as confounded with his own subjectivity or as expressing the dharma. One of his haikus presents a frog embraced and included within the Buddha's compassionate scope in a very explicit way:

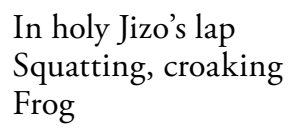

Jizo is a bodhisattva who rescues beings regardless of them being good or bad and regardless of them asking for her help ${ }^{12}$. As a Jodo Shin Buddhist Issa would have regarded Jizo as a manifestation of Amida Buddha, but when the Buddha appears more actively engaged with beings s/he is presented as a Bodhisattva. By placing the frog on the Bodhisattva's lap Issa explicitly presents the amphibian as the object of the Buddha's compassion. In other words, Issa asserts the equal relationship between the frog and himself: they are both the recipients of the Buddha's compassion; they both sit at her lap and talk.

Another remarkable instance of frogs teaching the dharma to Issa can be found in this haiku in which the frog reminds the poet about his own mortality:

Frogs at my hut

From the beginning have sung

"We grow old"

Here the frog acts as a Buddhist teacher or as the Buddha himself, awakening the narrative self from its delusive believe in permanence and stability. Interestingly enough, the frogs' voice precede the poet's noticing. It seems like the frogs have been teaching the dharma for a long time and only now, at the time that this haiku is written, the poet realizes what they have been saying all along. Again, the frogs appear wiser than the poet, although their superior position is not expressed in a condescending way, but as a constant reminder. In this haiku the frogs fulfil the

12 Not unlike Amida, the Bodhisattva Jizo started as a male figure in India, but through China and Japan was transformed into a far more ambivalent and androgynous figure. A comprehensive discussion of the cult of Jizo can be found in Bay's Jizo Bodhisattva. 
function of their homonym 'return', as they can be said to bring the poet back to an awareness of his own mortality.

A similar portrayal of frogs and their voice as returners or reminder of the teaching of the Buddha, which precedes the poet and permeates all existence can be found in this later haiku:

In every direction

Ten thousand blessings...

Croaking frogs

In this case the frogs' croaking is identified with "ten thousand blessings" pervading "every direction". The language employed here resembles the one employed in the Buddhist sutras for referring to the all-pervasive voice of the Buddha. In fact, a scripture often recited in Jodo Shinshu temples (Sambutsuge) speaks of it in the following manner: "the great voice resounds throughout the ten quarters" (Jodo 12). Issa accesses this "great voice", which stands as a metaphor for the teaching of the Buddha, and, thus, for interdependence itself, through the "croaking frogs". Their ability to speak communicates to Issa "ten thousand blessings", the realisation of interconnection. In this context, Issa might be said to be following Shinran's advice by listening to others. In his quest for the dharma he does not stop at temple sermons, he goes further to find the dharma among other others.

A very significant example of a frog appearing as a guide to a human, framed in the narrative of Amida grasping the unreliable human subject, is found in this haiku from 1812:

Crossing the bridge

Behind a blind man

A frog

The bridge symbolizes the path to the "other shore", which in the Buddhist imagination stands for nirvana, Buddhahood or the Pure Land. The blind man is an unawakened human being wishing to cross over to the realm of awakening, but his endeavour is a foolish one since he cannot see the path ahead of him. However he is not abandoned; a frog jumps after him in order to help him. This haiku can be seen as a dramatization of the jiriki / tariki dynamics. The narrative self (the blind man) tries to walk the path that promises to see him through his own efforts (jiriki), but those very efforts blind him further, making the crossing dangerous. Nonetheless, and although he might not be aware of it, there's a helping agency outside himself (tariki) ready to assist him in his quest. The man does not yet realise that he cannot make it to the other end of the bridge, but the frog is ready to help from the very beginning. Thus the frog is identified with Amida's compassionate agency, which plays the part of a guide for those who cannot see the path ahead.

In the same way that frogs seem to precede the poet they also seem to outlive him. The last haiku chosen for this discussion seems to witness the fading of the poet's voice giving way to the frog's: 
Taking up the holy man's

Chant...

Croaking frogs

The holy man's (shonin) voice, which could be Shinran or the Buddha, seems to fade and instead his chant is carried on by the frogs. The identification between the dharma and the frogs' voice could not be more explicit. The haiku could be interpreted as implying that the frogs learn the chant from the holy man, but also as meaning that once the holy man is gone, his teaching remains through the frogs' croaking. Issa seems to find the "chant of the holy man", which could well be the nembutsu, in the frogs' voice. The precondition for such finding is of course Issa's listening, which enables the other to decentre the self. The isolated poet's self opens to the frog voice and in so doing finds empathy, flowing both towards his self and outwards back at the frogs. Through this communication the centrality of the poetic voice is eroded, if not demolished, and the voices of the croaking frogs are brought to the fore.

So, can the frog speak in Issa's poetry? After years wrestling with Gayatri Spivak's "Can the Subaltern Speak?" I have become convinced that when the issue of voice is framed in this way the question becomes unanswerable. It seems not a matter of whether the frog can or, indeed, does speak (which they obviously do) but whether they are been listened to in Issa's haikus. It seems that they are listened to, and therefore we can hear the frogs' voices. The poet sometimes learns from them as they embody the sound of the dharma or the Buddha's voice (the most valuable thing in his symbolic universe), at times he is offering them his help and sometimes he merges with them non-verbally but verbalizes the experience in a way that dismantles discursive hierarchies and structures of power. This fluid relationship brings into question the very boundaries of Issa's position as human and, therefore, the authoritarian prerogatives of the human subject.

Nevertheless, it could be argued that frogs become a mere mouthpiece for Issa's religious ideology. They do not really speak but are made to say what Issa really wants to hear / say. Whereas this is a valid point and it is to some extent true when reading the voices of others through the writings of a literary subject, it is worth remembering that Issa's view of subjectivity, agency and voice are not strictly anthropocentric. By making them the Buddha's messengers, Issa obscures not only the frog's voice and agency but also his own, in order to give birth to the collective agency of tariki in which his poetic voice, the frog's croaking and the Buddha's teaching become intertwined. He is not letting the frogs speak in their own terms, but through the mediation of his religious sentiments. Nonetheless, as imperfect and anthropocentric as this religious framework might be, it allows Issa to place the non-human other as equal and, at times, even above himself. It also enables the human and the non-human to converse and learn from each other, albeit in the terms and language of the human subject.

To sum up, it is precisely this Shin Buddhist framework, modified in Issa's own literary and strongly personal way, what makes him listen to frogs and engage in a self-decentring that has clearly egalitarian and anti-speciest implications. Issa's 
voice provides a fresh approach to discussions about non-human agency and voice, coming from an ideological milieu in which both agency and voice are regarded as fluid, interdependent and collective. In consonance with this view, Issa's frog haikus might be regarded as records of small encounters with non-human others that make him question or reappraise himself. Through this encounters discursive power relations that place non-human subjects below the human are disrupted, making Issa's work relevant not only to ecocritical discussions about agency but also to anti-speciest anarchism. Being grounded in a narrative that regards (self-) decentering as natural (jinen) and positive, Issa takes (self-)decentering one step further by extending the latently subversive and liberatory logic of Jodo Shinshu Buddhism to non-human others. 


\section{WORKS CITED}

Aвram, David: The Spell of the Sensuous: Perception and Language in a More-Than-Human World. New York: Vintage, 1997.

BAys, Jan Chozen: Jizo Bodhisattva: Guardian of Children, Travelers and Other Voyagers. Boston: Shambhala Publications, 2002.

Best, Steven: "Rethinking Revolution: Total Liberation, Alliance Politics, and a Prolegomena to Resistance Movement in the Twenty-First Century". Contemporary Anarchist Studies. An Introductory Anthology of Anarchy in the Academy. Ed. Randall et al. New York: Routledge, 2009. 189-99.

Bloom, Alfred: "Honen and Shinran: Loyalty and Independence". Shin Dharma Net. http://www. shindharmanet.com/wp-content/uploads/2012/pdf/Bloom-Loyalty.pdf. Last accessed: October 25th 2013.

Bloom, Alfred: Strategies for Modern Living: A Comentary with the Text of the Tannisho. Berkeley, California: Numata Centre for Buddhist Translation and Research, 1992.

Blum, Mark: The Origins and Development of Pure Land Buddhism: A Study and Translation of Gyonen's Jodo Homon Genrusho. Oxford: Oxford University Press, 2002.

Bookchin, Murray: "Social Ecology versus Deep Ecology: A Challenge for the Ecology Movement from Murray Bookchin". Anarchy Archives: An Online Research Centre on the History and Theory of Anarchism. June 25 ${ }^{\text {th }}$ 1987. http://dwardmac.pitzer.edu/Anarchist_Archives/ bookchin/socecovdeepeco.html. Last accessed. October 25th 2013

Dobbins, James: Jodo Shinshu: Shin Buddhism in Medieval Japan. Bloomington and Indianapolis: Indiana University Press, 1989.

Jodo Shinshu Service Book. Kyoto: Jodo Shinshu Hongwanji-ha, 2013.

Jones, David: "Animal Buddhas". Buddha Nature and Animality. Ed. David Jones. Fremont, California: Jain Publishing House, 2007.

Jones, Pattrice: "Free As a Bird. Natural Anarchism in Action". Contemporary Anarchist Studies. An Introductory Anthology of Anarchy in the Academy. Ed. Randall et al. New York: Routledge, 2009. 236-246.

Kasahara, Toshinori: "Shin Buddhism and the Buraku-min". Shin Dharma Net. October 17, 1996. http://www.shindharmanet.com/wp-content/uploads/2012/pdf/Kasahara-Burakumin.pdf. Last accessed October 25th 2013.

Kenmyo, Takagi: "My Socialism". Robert Rhodes (trans.). Alfred Bloom (ed.) Living in Amida's Universal Vow. Essays on Shin Buddhism. Boston: Wisdom, 2004. 189-196.

Коваyashi Nobuyuki, Issa: Haiku of Kobayashi Issa. Trans. David G. Lanoue. 1991-2013. http:// haikuguy.com/issa/. Last accessed: October 25th 2013

Lanoue, David G.: Pure Land Haiku: The Art of Priest Issa. Reno, Nevada: Buddhist Books International, 2004.

Macy, Joanna: Mutual Causality in Buddhism and General Systems Theory: The Dharma of Natural Systems. Albany: State University of New York Press, 1991.

Manes, Christopher: "Christopher Manes". Listening to the Land: Conversations about Nature, Culture and Eros. Ed. Derrick Jensen. White River Junction, Vermont: Chelsea Green Publishing House, 2004. 14-23. 
Marshall, Peter: "Taoism and Buddhism". Demanding the Impossible: A History of Anarchism. London: Harper Perennial, 2008.

Rutschman-Byler, Hondo Dave: "Enclothed Cognition and the Robe of the Buddha". No Zen in the West. April 20 th 2012. http://nozeninthewest.wordpress.com/2012/04/20/enclothedcognition-and-the-robe-of-buddha/. Last accessed October 25th 2013.

Shigaraki, Takamaro: Heart of the Shin Buddhist Path: A Life of Awakening. Trans. David Matsumoto. Boston: Wisdom Publications, 2013.

Shimazu, Esho: “The Sangowakuran Incident and its Significance for Engaged Buddhism. Muryoko. Journal of Shin Buddhism. http://www.nembutsu.info/sangowakuran.htm. Last Accessed October $25^{\text {th }} 2013$.

Shinran: "Notes on Essentials of Faith Alone". Collected Works of Shinran. Vol 1. Ed. Dennis Hirota. Kyoto: Jodo Shinshu Hongwanji-ha, 1997. 441-469.

Shinran: "On Jinen Honi". Letters of Shinran: A Translation of Mattosho. Ed. Yoshifumi Ueda. Kyoto: Hongwanji International Centre, 1978.

SNYDER, Gary. "Buddhist Anarchism”. Bureau of Public Secrets. 2002 [1961]. http://www.bopsecrets. org/CF/garysnyder.htm. Last Accessed October 25 2013.

SPIVAK, Gayatri Chakravorty: “Can the Subaltern Speak?”Colonial Discourse and

Postcolonial Theory: A Reader. Ed. Patrick Williams and Laura Chrisman. New York: Harvester Wheatsheaf, 1993. 66-111.

Takayama, Sadami: Shinran's Conversion in the Light of Paul's Conversion. Rome: Editrice Pontificia Universita Gregoriana, 2000.

Unno, Taitetsu: Shin Buddhism: Bits of Rubble Turn into Gold. New York: Random House, 2002.

Victoria, Brian Daizen: Zen At War. New York: Rowman and Littlefield Publishers, 2006. 
